\title{
AHR Gene
}

National Cancer Institute

\section{Source}

National Cancer Institute. AHR Gene. NCI Thesaurus. Code C28523.

This gene is involved in the regulation of xenobiotic-metabolizing enzymes. 